
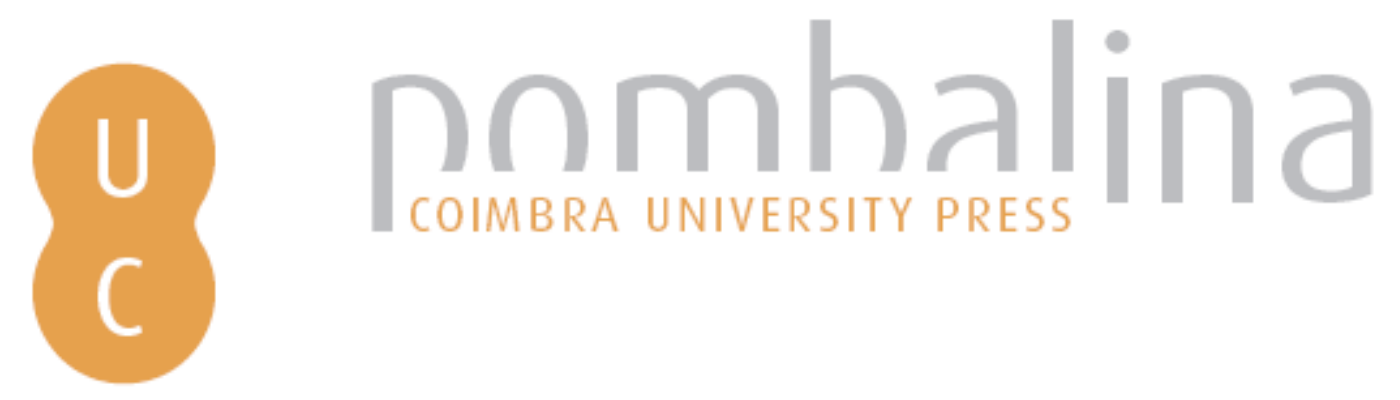

\title{
The role of parental support in sports sucess of talented young dutch athletes
}

Autor(es): $\quad$ Visscher, Chris; Elferink-Gemser, Marije T.; Lemmink, Koen AP.M.

Publicado por: Coimbra University Press

URL

persistente: URI:http://hdl.handle.net/10316.2/32601

DOI: $\quad$ DOI:http://dx.doi.org/10.14195/978-989-26-0412-1_8

Accessed : $\quad$ 26-Apr-2023 10:44:37

A navegação consulta e descarregamento dos títulos inseridos nas Bibliotecas Digitais UC Digitalis, UC Pombalina e UC Impactum, pressupõem a aceitação plena e sem reservas dos Termos e Condições de Uso destas Bibliotecas Digitais, disponíveis em https://digitalis.uc.pt/pt-pt/termos.

Conforme exposto nos referidos Termos e Condições de Uso, o descarregamento de títulos de acesso restrito requer uma licença válida de autorização devendo o utilizador aceder ao(s) documento(s) a partir de um endereço de IP da instituição detentora da supramencionada licença.

Ao utilizador é apenas permitido o descarregamento para uso pessoal, pelo que o emprego do(s) título(s) descarregado(s) para outro fim, designadamente comercial, carece de autorização do respetivo autor ou editor da obra.

Na medida em que todas as obras da UC Digitalis se encontram protegidas pelo Código do Direito de Autor e Direitos Conexos e demais legislação aplicável, toda a cópia, parcial ou total, deste documento, nos casos em que é legalmente admitida, deverá conter ou fazer-se acompanhar por este aviso.

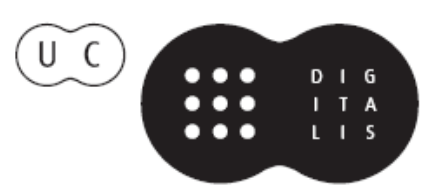


MANUEL COELHO E SILVA

ROBERT M. MALINA

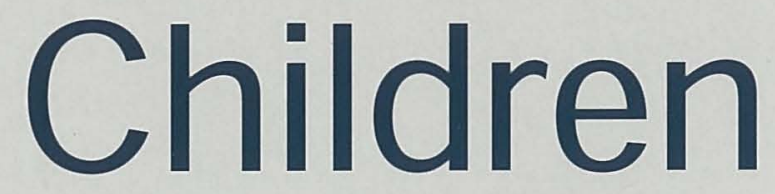

\section{and Youth}

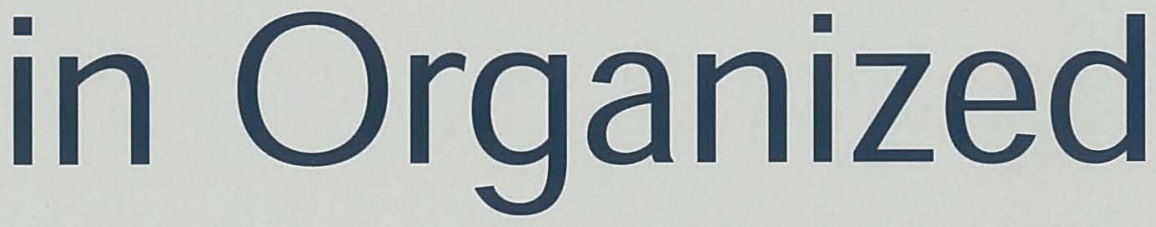

Sports 
(Página deixada propositadamente em branco) 
Manuel Coelho e Silva

Robert M. Malina

(Editors)

CHILDREN AND YOUTH IN ORGANIZED SPORTS

COIMBRA UNIVERSITY PRESS

2004 


$$
\begin{gathered}
\text { Editors } \\
\text { Manuel Coelho e Silva } \\
\text { and } \\
\text { Robert M. Malina } \\
\text { Publisher } \\
\text { Imprensa da Universidade de Coimbra } \\
\text { Coimbra University Press } \\
\text { Title } \\
\text { Children and Youth in Organized Sports }
\end{gathered}
$$

Date

March 2004

ISBN

972-8704-21-6

(Depósito legal n.: 208058/04)

Financial support

FCT Fundação para a Ciência e a 'Tecnologia MINISTÉRIO DA CIÊNCIA E DO ENSINO SUPERIOR Portugal

$$
\text { Apoio do Programa Operacional }
$$

Ciência, Tecnologia, Inovação do Quadro Comunitário de Apoio III

e

Câmara Municipal da Lousã

Faculdade de Ciências do Desporto e Educação Física

Universidade de Coimbra 


\title{
THE ROLE OF PARENTAL SUPPORT IN SPORTS SUCCESS OF TALENTED YOUNG DUTCH ATHLETES
}

\author{
Chris Visscher \\ Marije T. Elferink-Gemser \\ Koen A.P.M. Lemmink \\ Institute of Human Movement Sciences. University of Groningen. THE NETHERLANDS
}

\section{INTRODUCTION}

Until the middle of the 20th century, it was possible to become an international athlete without belonging to a nation's group of most-talented individuals (Bouchard et al., 1997). The selection process was less stringent and the level of competition was not as demanding as it is today. As a result of the growing importance of sports success in society, the continuous increase in the number of young athletes and the growing sophistication of training, psychological preparation, equipment and facilities, the level of competition has increased to the point that only the extremely gifted are potentially able to reach elite status. Talented athletes often begin intensive and timeconsuming training at increasingly younger ages (Alabin et al., 1980; Hahn, 1990). When a young athlete choses to develop his/her talent in order to reach elite status, this has major consequences for lifestyle. The process is long, averaging at least 10 to 12 years, and during this interval, significant others, particularly parents, play an important role.

Behavior of parents can have a positive effect on the sport behaviors of their children (Visscher et al., 1996a). Family environment is an important factor in the development of talented young athletes (Ericsson, 1996), parental modeling is an important influence on children's acquisition of positive values, attitudes and behaviors toward sports and physical activity (Côté, 1999). According to Giljam (1988), however, there is a distinction in parental support between serving as a role model and giving stimulation towards athletic involvement and success in sports.

The present study attempts compares the parental support given by parents of more successful and less successful talented athletes. All athletes were originally designated as exceptionally talented, and the differentiation between them in terms of degrees of success occurred across time. The study addressed two questions:

Do parents of more successful athletes provide a better role model for their child's achievements in sports than parents of less successful athletes? 
Do parents of more successful athletes stimulate their child more towards better achievements in sports than parents of less successful athletes?

\section{THEORETICAL CONSIDERATIONS}

Bouchard et al. (1997) described the elite athlete as an individual with a sports-specific profile in terms of morphological, physiological, metabolic, motor, perceptual, psychological and biomechanical determinants. The elite athlete is also highly responsive to regular training and practice. Bloom (1985) stressed the role of the family by indicating that the development of exceptional talents requires family support, excellent teaching and appropriate motivational reinforcement at any stage of their development. Regardless of the quality of their initial talent, each of the individuals in Bloom's study went through many years of development and training under the care of attentive parents and the tutelage and supervision of several teachers and coaches. All of the talented individuals interviewed in the study invested a substantial amount of time on practice and training, which clearly competed with time devoted to school and other activities. They indicated that the time invested in athletic performance was far more rewarding than that allocated to other activities. Athletic involvement was seen as a career, i.e., as a process with a beginning, a developmental trajectory, and an end.

Côté (1999) discussed the importance of parental influence on children's involvement and achievement in sports and other domains. Several authors (e.g., Bloom, 1985; Brustad, 1993; Hellstedt, 1987, 1995; Woolger and Power, 1993) have demonstrated that greater parental encouragement is associated with greater perceived physical competence in children. Parents of committed athletes are usually willing and happy to attend their children's competitions and tournaments, and are often present during practice sessions (Csikszentmihalyi et al., 1993; Monsaas, 1985; Sloan, 1985). There is a positive relationship between parental expectations and children's success and enjoyment of sports (McElroy and Kirkendall, 1980; Scanlan and Lewthwaite, 1985). Other studies, however, have shown that parental expectations may be a source of pressure and stress that can interfere with their children's participation in sports (Brustad, 1988; Scanlan et al., 1991; Visscher et al., 2003; Weiss et al., 1989), and that the relationship between parental expectations and children's enthusiasm may be curvilinear in some sports (Power and Woolger, 1994). Excessively high or low parental expectations are associated with less enthusiasm, while an intermediate level of expectation is associated with enthusiasm for swimming.

Although coaches have the most direct contact with children within the sports environment, parents are instrumental in determining children's sport 
involvement (Lewko and Greendorfer, 1988; McPherson and Brown, 1988). The "athletic triangle", i.e., coach, athlete and parent, is a natural feature of youth sports, and the role of the coach in relation to the parents is crucial for the success of a training program. Through their cooperative efforts, many parents contribute productively. Unfortunately, the negative impact of some parents is all too obvious. Some parents can undermine the basic goals of youth sport programs and deny youngsters of benefits that can be derived from participation. Most of the negative consequences in youth sports occur when adults erroneously impose a professional model on what should be a recreational and educational experience for children.

When excessive emphasis is placed on winning, it is easy to lose sight of the needs and interests of the young athlete. Hellstedt (1987) described parents' involvement in their children's sports career on a continuum from under-involved to moderately involved to over-involved. The moderate level of involvement describes parents who promote the best interests of their children, even if it means sacrificing personal interests. Bloom (1985) underscores the major influence of the family at different stages of talent development in science, art and sport, reporting that in the early years of children's involvement in one of these activities, parents tend to be supportive, allowing them freedom to decide whether to practice or not. This is followed by a period of dedication for both performers and parents. The later years are characterized by the individuals' full-time commitment to improving performance and the parents' role is more restricted, consisting mainly of financial support. Blooms' study thus provides a developmental perspective for the influence of family on talent development.

The early stages of the careers of international athletes have been considered from an interactionistic perspective by Stevenson (1990). Socialization has been explained as a process of "identity formation" (Lauer and Handel, 1983). The person is seen as an active and self-reflective participant in this process. The process is concerned with the ongoing development and support of specific role identities that the athlete perceives to be desirable and valued (McCall and Simmons, 1978).

The influence of parents on the achievement of talented young athletes is thus obvious. There is a distinction, however, in parental support as a role model and as a stimulant for athletic involvement. Butcher (1985) suggests that a combination of the two has the best effect on involvement and success in sports. Giljam (1988) adds that parents should create those opportunities for their children that are necessary in order for them to have a successful athletic career. 


\section{RESEARCH IN TALENTED DUTCH CHILDREN}

\section{I. Definitions}

Parents serve as positive role models if they themselves are presently active in sports and/or have been in, the past. Stimulation of athletic involvement can be divided into three components: financial support, emotional support, and success in sports. Financial support relates to the costs incurred for the sake of a child's sport career. Parents also play an important role in providing emotional support. Emotional support is viewed as consisting of three parts: presence at training, competitions and tournaments; contact with the coach; and whether or not parents attach importance to there being a pleasant atmosphere in their child's sport team (Visscher et al., 1996b). The importance of success in sports is measured in two parts: the amount of pressure exerted on achievement and the value given to the social status parents can attain by way of their child's achievements in sports (Hahn, 1988).

\subsection{Participants}

In the Netherlands, talented young athletes are chosen to be part of a district selection team to develop their sport qualities with goal of competing at the national level. There are specific selections for individual and team sports. In the 14-16 year age group, there were 360 talented athletes who were members of the selection for the Northern part of The Netherlands in one of several sports: soccer, volleyball, field hockey, tennis, speed skating and judo. All athletes were asked to participate in the study. A total of 254 (71\%) did and completed a questionnaire. This group consisted of I 36 males (54\%) and II 8 females (46\%), and had an average age of 15 years and I month. The sample included 176 team athletes (69\%) and 78 athletes in individual sports (31\%).

Table I. Number of participants by gender and type of sport.

\begin{tabular}{lr|c|c|c}
\hline \multicolumn{1}{l}{ Sports } & & Male & Female & Total \\
\hline Team athletes: & & 93 & 83 & 176 \\
& Soccer & 52 & 38 & 90 \\
& Volleyball & 17 & 21 & 38 \\
& Field hockey & 24 & 24 & 48 \\
\hline Individual athletes: & & 43 & 35 & 78 \\
& Tennis & 12 & 7 & 19 \\
& Speed Skating & 12 & 18 & 30 \\
& Judo & 19 & 10 & 29 \\
\hline TOTAL & & 136 & 118 & 254 \\
\hline
\end{tabular}

Two years later, when the athletes reached the age group of 16-18 years, the trainers of the district selection teams determined whether or not the initial sample of 254 athletes could still be considered as talented, i.e., as 
successful in their respective sports. Athletes were viewed as more successful when they still performed at the highest national level for their age. For team sport athletes, this was competition at the highest national level for their age, and for athletes in individual sports, success was viewed as qualification for the national championship. Information on performance was available for 228 athletes (90\%), I4I (62\%) performing at a high level (more successful) and 87 (38\%) no longer performing at a high level (less successful).

\subsection{Data collection and data analyses}

A questionnaire, 'Parental Support in Sports,' was designed for the study (see appendix). Most questions were in closed format using 4 or 5 point Likert scales, but open questions were structured to obtain more in-depth information. Responses were compressed into three categories: "great parental support", "some parental support" and "no parental support". Data were reported as percentages.

Two years after the initial survey, trainers identified the athletes who were more and less successful in their respective sports. The trainers used a list with the names of all the athletes that participated in the study. The questionnaire responses of the more and less successful athletes were then compared:

All analyses have been done using SPSS/PC+. The variables measured with the questionnaire are on ordinal level and to make comparisons between both groups, we chose a non-parametric test (Huizingh, 1993; Stevens, 1996). This study deals with two independent groups - more successful and less successful athletes - and the test used to investigate significant differences is the Mann-Whitney test (also called Wilcoxon test). The level of significance (ㅁ) has been set at the 0.05 level.

\section{RESULTS}

\section{I. On role models}

Over $90 \%$ of the parents served as a role model at least in some way, and there was a significant difference between the more and less successful athletes $(p<0.05)$. Parents of more successful athletes were presently or in the past more active in sports than parents of the less successful athletes. This implies that parents of more successful athletes served as better role models. 


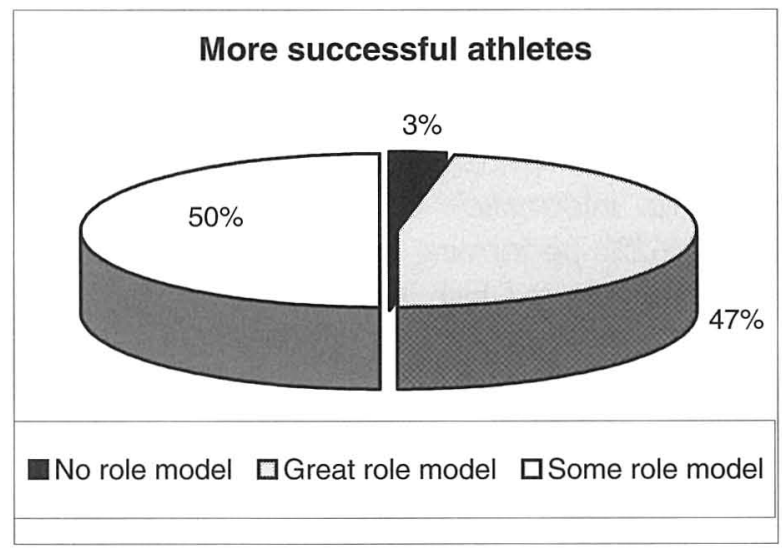

Figure Ia. Parental role modeling of youth athletes with high degree of success.

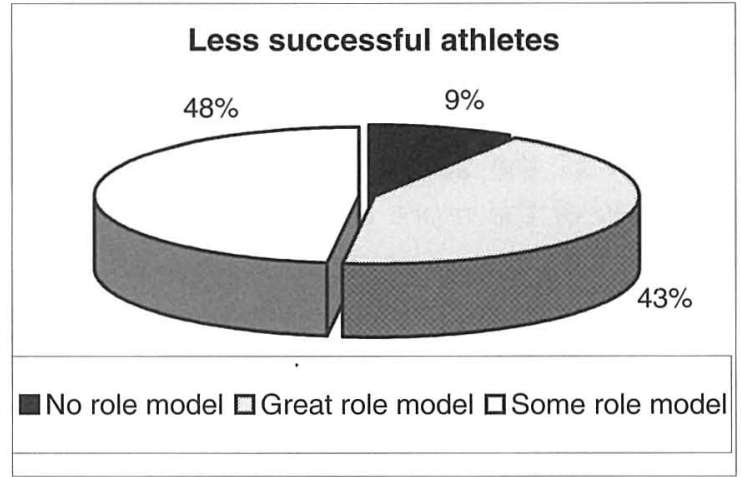

Figure Ib. Parental role modeling of youth athletes with low degree of success.

\subsection{On stimulation}

There was no difference between the two groups of athletes for financial support from parents. Parents of both the more successful and less successful athletes did not often discuss the costs that they incurred for their child's athletic career.

Over $75 \%$ of parents gave at least some emotional support, and the difference between more and less successful athletes was significant $(p<0.05)$. The more successful athletes received more emotional support from their parents. Parental emotional support consisted of presence at training sessions, competitions and tournaments; contact between parents and coaches; and 
whether parents attached importance to there being a pleasant atmosphere for their child's sport training.

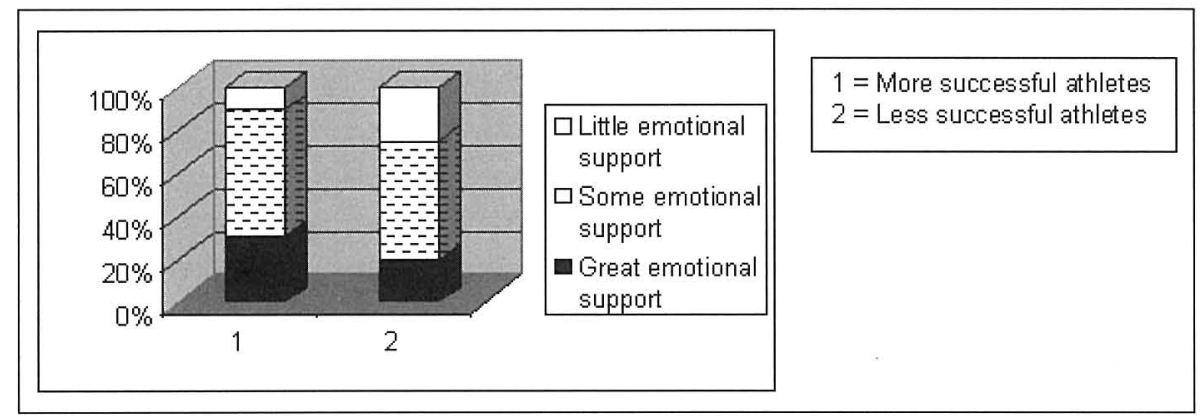

Figure 2. Parental emotional support of youth athletes with varying degrees of success.

There was no significant difference between the more and less successful athletes in the third component of stimulation, the "importance of success." At least 90\% of all parents in both groups believed that their child's achievements in sports were important to very important.

\section{DISCUSSION}

All athletes were considered to be talented for their sport at the time the questionnaire was completed. After two years, some of the athletes were still viewed as talented, i.e. were still successful, while others were viewed as less successful. The more successful athletes still competed at the highest national level, while the less successful athletes no longer did so. Comparison of the two groups with regard to parental support for sport provides insights into family patterns that may be important for a successful athletic career.

It is clear that over $90 \%$ of all parents served as a role model for sport participation in some form and that over $75 \%$ of all parents gave at least some emotional support regarding the sports involvement of their child. The results indicate, in general, that families of talented athletes provide a very positive sports climate. The present study also showed differences in parental involvement between more and less successful athletes. Parents of more successful athletes provided better role models for their children's athletic achievements and more stimulation toward better sports achievements.

Only emotional support showed a significant difference between the two groups. As a trainer or coach, it is important to realize that parents of talented athletes play an important role during the development of a sport 
career. Without parental support, it is hardly possible for a child to reach elite status.

Bloom (1985) distinguished among the Early, Middle and Later years in the careers of talented individuals. The influence of the parents was greatest during the Early Years as they urged their child towards athletic activities. It was during the Middle Years that a young athlete was ordinarily identified as talented, and the nature of parental support was largely emotional and financial. Parental support became less important in the Later Years. although financial support did continue to play some role. Athletes in the present study can be placed in the Middle Years, so that it is not surprising that emotional support is of particularly great importance. In general, these athletes do not yet have a partner to turn to for emotional support, as is often the case in the Later Years, and this makes it a serious task for the parents.

As a trainer or coach, it is important to have regular contact with parents. By keeping parents updated about the training process and progress, parents are better informed and can provide appropriate support. It is also important to realize that parents attendance at training sessions, competitions or tournaments is generally a positive sign. Of course, negative concerns for over-involved parents should not be ignored.

Training methods and facilities are obviously important to provide athletes with the best opportunities to develop their talent. The atmosphere within the group is also equally important. Parents of more successful athletes in the Netherlands realize that a pleasant atmosphere is important for their child, and attach more value to this dimension of sport than parents of less successful athletes.

To develop a successful career in one of the sports included in this study (soccer, volleyball, field hockey, tennis, speed skating or judo), young athletes invest at least 8 to 10 years of training before reaching the top. This is only possible if the athletes enjoy the activities, since feelings of enjoyment are related to high intrinsic motivation (Biddle and Chatzisarantis, 1999). It is also suggested that acquisition of expert performance involves operating within 130 three types of constraints, including a motivational constraint (Ericsson et al., 1993). Trainers and coaches can contribute to the development of a successful sports career by, among other things, creating a pleasant atmosphere.

The differences observed between more and less successful athletes were already apparent when the total sample was still considered to be successful since they all competed at the highest national level for their age group and it was not yet apparent who would ultimately become more successful. Of course, there are many different variables that play important 
roles in the development of a successful sport career, including physical and mental qualities. It is also clear that parental support is important, since in most cases it is the parents who are part of the child's life during the course of the entire athletic career. Parents can serve as role models and can stimulate their child towards better achievements in sport and in school.

\section{CONCLUSION}

It can be concluded that both serving as a role model and providing emotional support are important to success in sport. There are differences between parents of athletes who are more and less successful over the long run, although it is not possible to affirm that parental support is the decisive factor.

The role of the parents in the sport involvement of talented youngsters is complex and the diversity of family contexts needs consideration (Côté, 1999). The complete family environment needs consideration at each stage of a young athlete's development in order to understand the influence of parents and family dynamics on talent development.

\section{REFERENCES}

Alabin V, Nischt G,. Jefimov W (1980). Talent selection. Modern athlete and coach. 3637.

Biddle $\mathrm{J}$, Chatzisarantis $N$ (1999). Motivation for a physically active lifestyle through physical education. In Y Vanden Auweele, F Bakker, S Biddle, M Durand, R Seiler (Eds.). Psychology for Physical Educators (5-26). Leeds. UK: Human Kinetics.

Bloom BS (1985). Developing talent in the young. New York: Ballantine.

Bouchard C, Malina RM, Pérusse L (1997). Genetics of fitness and physical performance (365-37I). Champaign. IL: Human Kinetics.

Brustad RJ (1988). Affective outcomes in competitive youth sport: The influence of intrapersonal and socialization factors. Journal of Sport \& Exercise Psychology. 10. 307321.

Brustad RJ (1993). Who will go out and play? Parental and psychological influences on children's attraction to physical activity. Pediatric Science. 5. 210-223.

Butcher J (1985). Longitudinal analysis of adolescent girl participation in physical activity. Sociology of Sport Joumal. 12.91-99.

Côté J (1999). The Influence of the Family in the Development of Talent in Sport. The Sport Psychologist. 13. 395-417.

Csikszentmihalyi M, Rathunde K, Whalen S (1993). Talented teenagers: The roots of success and failure. New York: Cambridge.

Ericsson KA (1996). The acquisition of expert performance: An introduction to some of the issues. In KA Erisccon (Ed.). The road to excellence: The acquisition of expert performance in the arts and sciences. sports and games ( I-50). Manwah. NJ: Lawrence Erlbaum.

Ericsson KA, Krampe R, Tesch-Römer C (1993). The role of deliberate practice in the acquisition of expert performance. Psychological Review. 100 (3). 363-406. 
Giljam MJ (1988). Sportgedrag en levensloop: een kwalitatief onderzoek naar achtergronden van de sportdeelname in de gemeente Rotterdam. Culemborg: Bruno.

Hahn A (1990). Identification and selection of talent in Australian rowing. Exel. 6. 5- I I.

Hahn E (1988). Jeugdtraining. Uit de serie Sport. Theorie en Praktijk. Baarn: Uitgeverij Tirion Sport.

Hellstedt JC (1987). The coach/parent/athlete relationship. The Sport Psychologist. I. $|5|-\mid 60$.

Hellstedt JC (1995). Invisible players: A family system model. In SM Murphy (Ed.). Sport Psychology Interventions ( I 17-|46). Champaign. IL: Human Kinetics.

Huizingh, E (1993). Inleiding SPSSIPC+ 5.0 en Data Entry. Addison-Wesley Nederland BV.

Lauer RH, Handel WH (1983). Social psychology: The theory and application of symbolic interactionism. Englewood Cliffs. NJ: Prentice-Hall.

Lewko $J$, Greendorfer SL (1988). Family influences in sport socialization of children and adolescents. In FL Smoll, RA Magill, MJ Ash (Eds.). Children in sport (3rd ed.) (287-300). Champaign. III.: Human Kinetics.

McCall GJ, Simmons JL (1978). Identities and interactions. New York: The Free Press.

McElroy MA, Kirkendall DR (1980). Significant others and professionalized sport attitudes. The Research Quarterly for Exercise and Sport. 51. 645-653.

McPherson BD, Brown BA (1988). The structure. processes. and consequences of sport for children. In FL Smoll, RA Magill, MJ Ash (Eds.). Children in sport (3rd ed.) (265-286). Champaign. III.: Human Kinetics.

Monsaas JA (1985). Learning to be a world-class tennis player. In BS Bloom (Ed.). Developing talent in young people (21 |-269). New York: Ballantine.

Power TG, Woolger C (1994). Parenting practices and age-group swimming: A correlational study. Research Quarterly for Exercise and Sport. 65(I). 56-66.

Scanlan TK, Lewthwaite R (1985). Social psychological aspects of competition for male youth sport participants: III. Determinants of personal performance expectancies. Journal of Sport Psychology. 7. 389-399.

Scanlan TK, Stein GL, Ravizza K (1991). An in-depth study of former elite figure skaters: III. Sources of stress. Journal of Sport and Exercise Psychology. I3. $103-120$.

Sloan LA (1985). Phases of Learning. In BS Bloom (Ed.). Developing talent in young people. New York: Ballantine.

Stevens, J (1996). Applied multivariate statistics for the social sciences. 3rd Edition, Lawrence Erlbaum Associates Publishers, New Jersey.

Stevenson CL (1990). The Early Careers of International Athletes. Sociology of Sport Journal. 7. 238-253.

Visscher C, Gemser MT, De Greef MHG (1996.a). Jeugdige topsporters. invloed van ouders en onderwijs I. Richting-Sportgericht. 3.

Visscher C, Gemser MT, De Greef MHG (1996.b). Jeugdige topsporters. invloed van ouders en onderwijs 2. Richting-Sportgericht. 4.

Visscher, C, Bakema, R, Elferink-Gemser, MT, Lemmink, KAPM (2003). Waarom jeugdige topturners ermee stoppen. Richting Sportgericht.

Weiss MR, Wiese DM, Klint KA (1989). Head over heals with success: The relationship between self-efficacy and performance in competitive youth gymnastics. Journal of Sport and Exercise Psychology. II. 444-45I. 
Woolger C. Power RG (1993). Parent and sport socialization: Views from the achievement literature. Journal of Sport Behavior. 16. 3, 171-189.

\section{APPENDIX}

Dimensions of the Questionnaire 'Parental Support in Sports', with questions, scales and guidelines for data analysis.

\section{Parental Support in Sports}

\section{A. Role model}

Was your father or your mother participating in sports in the past?

Yes, they both were

Yes, my father

।

Yes, my mother

No, they were not

Is your father or your mother currently participating in sports?

Yes, they both are

Yes, my father

Yes, my mother

No, they are not
2

3

4
2

3

4

B. Stimulation of athletic involvement

\section{B. I. Financial support}

Do your parents talk about the costs they have to make with regard to your involvement in sports?

Very often

Often

Sometimes

Hardly ever

Never

\section{B.2. Emotional support}

Do your parents (or one of your parents) attend your training?

No, never 5

No, hardly ever 4

Sometimes

Yes, often

Yes, very often 
Do your parents (or one of your parents) attend your games/mathes/races?

No, never 5

No, hardly ever 4

Sometimes 3

Yes, often 2

Yes, very often

Do your parents talk with your trainer/coach about your sports involvement?

Yes, very often

Yes, often 2

Sometimes 3

No, hardly ever 4

No, never 5

Do your parents think it is important there being a pleasant atmosphere in your sport team?

No, not important at all 5

No, not so important 4

I don't know 3

Yes, important 2

Yes, very important ।

\section{B.3. The importance of success in sports}

Do your parents think it is important that you are performing at a high level in sports?

Yes, very important

Yes, important 2

I don't know 3

No, not so important 4

No, not important at all 5

Do your parents think it is important that you win a game/match/race?

Yes, very important ।

Yes, important 2

I don't know 3

No, not so important 4

No, not important at all 5

Do your parents think it is important that other people think highly of you because of your achievements in sports?

$\begin{array}{ll}\text { Yes, very important } & \text { I } \\ \text { Yes, important } & 2 \\ \text { I don't know } & 3 \\ \text { No, not so important } & 4 \\ \text { No, not important at all } & 5\end{array}$


Categories for role model:

Great role model $=$

$2-3$

Some role model $=$

$4-6$

No role model $=$

7-8

Categories for financial support:

Talk about the costs (very) often $=$

Talk about the costs sometimes $=$

3

Talk about the costs hardly ever or never $=$

Categories for emotional support:

Great emotional support $=$

4-8

Some emotional support $=$

$9-12$

Little emotional support $=$

13-20

Categories for importance of success in sports:

Great value =

3-8

Some value $=$

$9-12$

Little value $=$

13-15 
Série

Investigacão

Coimbra

Imprensa da Universidade

2004 